book review

\title{
Theoretical Stories
}

\section{TANYA SERISIER}

UNIVERSITY OF WESTERN SYDNEY

\section{Clare Hemmings}

Why Stories Matter: The Political Grammar of Feminist Theory

Duke University Press, Durham \& London, 2011

ISBN: 9780822349167 (pb)

RRP: US $\$ 23.95$

Janet Halley \& Andrew Parker (eds)

After Sex? On Writing Since Queer Theory

Duke University Press, Durham \& London, 2011

ISBN: 9780822349099 (pb)

RRP: US\$23.95

Clare Hemming's book, Why Stories Matter: The Political Grammar of Feminist Theory, and Janet Halley and Andrew Parker's collection, After Sex: On Writing Since Queer Theory, reflect, as their subheadings indicate, on the academic disciplines of queer and feminist theory. Specifically, both are works that consider how feminist 
and queer theorists understand their disciplines and how this understanding helps shape the possibilities of the theory they produce.

While the two fields discussed here have their own discrete histories and identities, the resonances between them go beyond their overlapping concerns with issues of sex and gender. Both feminist and queer theory have gone from being marginal voices within the academy to relatively established disciplines with their own apparatus of canonical journals, authors and texts. Both have, in short, acquired a 'past', as Janet Halley and Andrew Parker phrase it in the introduction to their collection. (1) And with that past has come a set of shared stories that shape participants' understanding of their disciplines and their role within them.

In both cases, too, this past involves outliving the activist movements that gave them their initial impulse-leading to questions about the disciplines' continued relevance and fidelity to their original aims, often expressed in debates about institutionalisation. At its most extreme, this has produced an uncomfortable sense of both disciplines as anachronistic or as having left their best times behind them. Clare Hemmings writes in relation to the feminist stories that she analyses, 'in each narrative vein, feminism is always surpassed'. (136) Similarly, Janet Halley and Andrew Parker note in discussing the impetus for their collection, 'we'd been hearing from some quarters that queer theory, if not already passé, was rapidly approaching its expiration date.' (7)

This is the historic and institutional context of both these texts, and the concerns of both are similar, albeit addressed in very different ways. Janet Halley and Andrew Parker ask their contributors and their readers: 'What has queer theory become now that it has a past?' (1) Hemmings, on the other hand, describes her purpose as to investigate 'how feminists tell stories about Western feminist theory's recent past, why these stories matter, and what we can do to transform them'. (1) In short, both works are intimately concerned with how our present understandings of the past shape the future possibilities of feminist and queer thought in the academy and elsewhere. While they are very different works this similarity in focus allows them to be productively read alongside each other.

Hemmings' particular interest is in what she describes as the 'technologies of the presumed' in feminist stories of the past. (1) These are those elements of feminist history that have become commonsense in the field, the claims made in 
articles in feminist journals that do not require evidence or citation because they are accepted as true. Looking for these elements in 'gloss paragraphs, introductions or segues in articles that told a story about feminist theory's development' from a number of leading feminist journals, Hemmings identifies three dominant ways of telling the story of feminist theory's development from the 1970s onwards. (17-8) Hemmings terms these 'progress', 'loss' and 'return' narratives and she notes that all three will be easily recognisable to anyone familiar with feminist theory. The truth of this claim is evident from a very brief synopsis of the three major arguments.

Hemmings claims that her first category, the 'progress' narrative, depicts the feminism of the 1970s as admirably passionate but relatively unreflexive and marked by assumptions of presumed universality and essentialism. These were challenged in the 1980 s by feminists of colour and lesbian feminists, who in critiquing their own exclusion from the feminist category of 'woman' paved the way for the more theoretically sophisticated critiques of poststructuralists, postcolonialists and queer theorists who, in the 1990s, introduced the diversity of feminist theory that we know today. The 'loss' narrative uses similar time periods but attaches very different values to them. In this narrative, the 1970s and 1980s were a time when feminist theory had a clear political objective and was firmly grounded in grassroots movements. The critiques of lesbian and black feminists in the 1980s were testament to the strength and diversity of feminist theory and politics, rather than an indictment. The 1990s, however, saw the increasing institutionalisation of feminist theory within the academy, which resulted in a depoliticisation and fatal attraction to the 'language games' of poststructuralism. The final narrative, 'return', charts a middle course between these two. While it acknowledges the importance of poststructuralist critiques of 1970s' feminism it argues that the 'cultural' or 'linguistic' turn in feminism was taken too far. Thus, feminism needs to return to its heyday of the 1970 s but in a way that is able to incorporate diversity and anti-essentialism.

For Hemmings, what is most significant about these narratives is not what differentiates them but what they share. As she argues, 'they make up the "presumed" of Western feminist stories, and together they make it hard to think about telling these stories in different ways'. (132) Her focus is particularly on the ways their shared historical and generational narratives not only mask actual 
debates and changing contexts but make them overly amenable to anti-feminist discourses and timelines. For instance, in positioning 1970s-era feminist concerns as 'surpassed' or 'over', either fortunately or unfortunately, all three narratives resonate too easily with post-feminist discourses in the West that see feminism as a relic of the past or as something that only applies to non-Western women. In addition, these shared stories perform boundary-policing work, where authors identified as overly influenced by poststructuralism or queer theory are viewed as somehow external to feminist debates rather than participating within them. The problem therefore, Hemmings convincingly demonstrates, is not that these histories need to be 'corrected' but that there needs to be more attention paid to the work that taken-for-granted historiography performs in the present and the way it shapes the future of feminist politics and theories. (132)

After Sex is also interested in the relationship between history and theory in the present. The contributors to this volume are all influential authors within queer theory, and the editors have deliberately included what feminists would refer to as different generations: authors who have been publishing since the mid-1990s as well as authors who have primarily published within the last few years. The result is a variety of short responses to the provocation of the editors that combine reflections on the field, their own relationship to it, and what it means to them. What is interesting here is that these reflections are shaped in response to an exhortation by the editors to reflect on what in their work isn't queer, or, framed another way, what it means for them to write 'after sex'. (1) These are then organised thematically by the editors into sections on genealogies, affect and the anti-social, identities, the legacy of Freud and Foucault with a final longer piece by Eve Kosofsky Sedgwick, originally composed for a 2005 seminar. The wide range of responses to ideas of 'after' and 'outside' in the book indicates that queer theory has, at least until now, managed to avoid the hegemony of the linear historical narratives that Hemmings identifies in relation to feminism. This is perhaps because of the more extensive critiques of the notion of teleology itself that have been produced from within queer theory and which are productively revisited by several of the authors in this collection, including José Esteban Muñoz and Elizabeth Freeman.

Bringing together some of the most influential theorists working in the field this book represents a unique opportunity to explore the narratives and identities 
central to queer theorists. Almost all the pieces reflect on the author's own relationship to queer theory, and the links made between theory, autobiography and affect are one of the strengths of this collection. A notable exception is Lee Edelman's polemic 'Ever After' which rejects concerns with 'after sex' as an 'entry into social narratives that work to domesticate the incoherence, at once affective and conceptual, that's designated by "sex"'. (111) While this continues the critique of futurity that Edelman is known for, it is a shame that he doesn't take this opportunity to revisit issues of temporality and futurity from a new perspective. However, this chapter represents a rare missed opportunity in a collection that is marked by the willingness of its authors to critically reflect on personal moments of discomfort and ambivalence. Leo Bersani, for instance, who is, along with Edelman one of the authors most associated with the "antisocial thesis" in queer theory contributes a notable highlight in the exploration of his 'troubled response' to the practice of bare-backing which he finds 'sexually repellent and staggeringly irresponsible.' (105) Reflections on this practice even lead him here to find 'something both naive and dangerous' in his claims in earlier work that gay men's "obsession" with sex should be celebrated for its 'socially dysfunctional' and 'selfshattering' elements. (107) Bersani's piece clearly shows the value of the book's project of linking history, identity and affect.

These links are also central to Hemming's work and one of the most interesting ways they are explored are through her critical engagement with citation. One of the features of the book is how Hemmings makes this 'presumed' technology of history-making a point of critical intervention. In tracing the development of her three narratives, Hemmings cites the journal and year of the gloss rather than the author. This, she writes, is 'intended to shift priority away from who said what, away from thinking about feminist theory in terms of "good" and "bad" authors, and away from the lures of prior agreement'. (21) Despite the initial jarring nature of reading this sort of citation, it does help Hemmings make a convincing argument about the pervasiveness of the narratives without the temptation for the reader, or author, to make personalised judgement about the scholarly practice of individual authors. My curiosity at points to know the names of the authors she cited really only gave further vindication to Hemmings' method. 
The other intervention made into citation practices is described by Hemmings as 'recitation'. (180) Here she undertakes a close reading of the citation practices surrounding Judith Butler in feminist theory, arguing that, because of her strong association with poststructuralism and queer theory, Butler is often 'masculinised' in citation practices and presented as an interloper rather than a participant in feminist theory. Hemmings focuses on the ubiquitous linking of Butler to Foucault in feminist citation and the almost ubiquitous erasure of her intellectual debts to Monique Wittig and Luce Irigaray. In her chapter 'Citation Tactics' Hemmings 'recites' Wittig back into feminist citations of Butler, displacing the references to Foucault. While she acknowledges the limitations of this practice it demonstrates the potential of citation as a destabilising moment in disciplinary practice. This textual intervention does, as Hemmings argues, offer the potential for transforming feminist understandings of our own past and our own canon. I could not help but think of the potential for such a tactic in the story told about queer theory in After Sex, as one of the most striking features of this book was the seeming universal acceptance of a clearly delineated canon of central texts and authorsoften presented as emerging spontaneously out of the activist movements of the 1990s. Hemmings' technique of recitation could be usefully applied here in a way that would allow for the questions of 'after' sex to be linked to questions of 'before' or 'alongside'.

The question of citation draws attention to the fact that writers of theory are also necessarily readers of theory and many readers of these books will approach them from the perspective of writers themselves. Hemmings is clearly cognizant of this in her analysis and she argues convincingly that much of the rhetorical power of the narratives she discusses is in their affective appeals to their readers-and she clearly locates herself in this category. This affect is largely produced through an exhortation to the reader to be a 'good feminist subject' who, as Hemmings notes, must be both 'heroic and marginal.' (157) In a progress narrative, the author is one of those who is furthering the diversity and theoretical sophistication of feminist theory, moving it ever further away from the essentialism and false universalism of the 1970s despite the relentless pull back towards essentialism. The narrator of the loss narrative on the other hand locates herself as a holding on to the true political legacy of feminism and sees herself as the champion of those women outside the 
academy who have been forgotten and left behind by other feminist theorists. Significantly, however, the heroines of the progress and loss narratives are also the anti-heroines of the other. To be valorised by one is to be decried by the other. This positioning means in Hemmings' case that she is far more critical of loss and return than of progress narratives, and to her credit she makes her own affective investment a feature of her analysis: 'I should also say that I am really beginning to enjoy myself in this chapter, drawing out techniques of othering in loss narratives'. (78) As Hemmings notes, such strong emotions are worthy of investigation and her willingness to both perform and analyse her own affect in the book is a strength.

However, I can't help but think that Hemmings' own work performs a similar role for its author and a sympathetic reader. Reading the book, I find myself happily positioned as the kind of reader who is able, with Hemmings, to step back and analyse the discursive functioning of these narratives. This positive affect accumulates throughout reading the book. 'Yes, I recognise the narratives! Yes, their similarities are more significant than their differences! And yes, they limit the possibility to tell other stories!' While Hemmings is right to insist that she does not articulate a 'correct' reading of feminist history, she does infer a correct relationship to this history. (27) And, inevitably, it is one that shares much with the narratives it critiques. While I don't think that this detracts from the strength of Hemmings' analysis, I do think it is worth considering how some of the processes she critiques may be reproduced in the work performed here, and this reproduction seems more clear in the exhortation to be a 'good feminist subject'.

As a reader I felt positioned in After Sex in a quite different way and it seems to me that this indicates a significant difference between feminist and queer theory. While feminist theory is, as Hemmings clearly shows, attached to notions of heroism, queer theory has more deliberately engaged with negative affects such as shame and disgust. As Heather Love notes in her contribution, at 'it's most expansive, queer studies imagined a federation of the shamed, the alienated, the destitute, the illegitimate, and the hated'. (183) This centrality of negative affect to queer theory perhaps means that there is a lesser exhortation to heroism. However, this doesn't mean there isn't a clear sense as to what a 'good' queer subject might be. An interesting effect of how the editors have framed the collection around personal relations to what is 'not' queer is that rather than exhorting readers to heroism, the 
collection seems to give its authors, and therefore its readers, permission to refuse this subjectivity. Several authors take this opportunity to explore the productiveness for their work of being 'bad' queer theorists. Elizabeth Freeman, for instance, in an excellent chapter titled 'Still After' writes that that 'what isn't queer about my scholarship, most probably, is that I'm willing to take seriously people's longing for that relief, for the privilege of being ordinary'. (29) Heather Love, for her part, writes evocatively of her attachment to lesbian identity: 'Behind my work on affect, historiography, and the social, there is a lesbian lying in bed crying'. (180) These and other chapters, such as Richard Thompson Ford's chapter on race which begins by discussing his heterosexual but inter-racial marriage, successfully raise questions about what it means to be a good subject of queer theory in a way that invites the reader to also ask these questions.

Significantly, neither of these two books includes a conclusion. Hemmings finishes with her chapter on 'Affective Subjects' and After Sex concludes with the essay by Sedgwick. The lack of a conclusion is more notable in Why Stories Matter as the final chapter focuses primarily on critiquing the notions of empathy and agency. These two concepts are often put forward within feminist theory as solutions to the impasses it faces, and particularly as solutions to the problematic relationships between Western theorists and non-Western women. Hemmings does a good job of critiquing both of these notions but the critiques that she offers here are less original than the work contained in the first half of the book. These terms have been contested, as Hemmings notes, by a wide range of theorists and they also don't read as necessarily the most central of the concerns identified by Hemmings in her readings of dominant feminist narratives earlier. For this reason, of all the chapters of the book I found the last the least convincing. The lack of a conclusion is not so jarring in After Sex, as it is a very different project. However, it does add to my sense that what the books share is a sense of reaching towards something, rather than having arrived.

Interestingly, my feelings after reading both books find their most articulate expression in Sedgwick's contribution to After Sex, the essay that appears in place of a conclusion for the volume. In this essay, Sedgwick writes of Foucault's discussion of the repressive hypothesis in The History of Sexuality: 'Foucault seems to me to be far more persuasive in analysing this massive intellectual blockage than in finding 
ways to obviate it.' She continues by noting that this kind of 'conceptual impasse' is 'all too familiar: where it is possible to recognise the mechanism of a problem, but trying to remedy it, or even in fact articulate it, simply adds propulsive energy to that very mechanism'. (293) While I would not go so far as to say that Hemmings or the editors of After Sex have added propulsive energy to the problems they unearth I do feel that both are far more successful in identifying and, in Hemmings' case, providing an excellent analysis of existing problems, than in finding ways to obviate them. As Sedgwick notes with Foucault this is not only a common feeling when dealing with such questions, it is perhaps 'inevitable.' (293) In neither case, however, does it devalue the work produced, and that After Sex provides me with the tools for thinking through my reception of it is a clear indication of its worth. In the case of Hemmings' work, the most accurate piece of praise that can be given is that not only does the book provide a compelling articulation of 'why stories matter' but it also argues forcefully for the need for 'a present and a future with some unpredictability in them'. (226) The contribution that both books make is a shared commitment to keeping the future open, refusing to accept that the story of queer and feminist theory has been written, or that its ending can be known.

Tanya Serisier researches and teaches in cultural and gender studies at the University of Western Sydney. Her current research interests include autobiographical storytelling in feminist politics and the cultural politics of consent. 